Turkish Online Journal of Qualitative Inquiry (TOJQI)

Cilt 8, Sayı 2, Nisan 2017: 250-271

DOI: $10.17569 /$ tojqi.266028

Araştırma Makalesi

\title{
Sosyal Bilgiler Öğretmen Adaylarına Göre Sosyal Medyada Değerler ${ }^{1}$
}

\author{
Hıdır Karaduman², Tuba Çengelci Köse ${ }^{3}$, Önder Eryılmaz ${ }^{4}$
}

\begin{abstract}
$\ddot{O} z$
$\mathrm{Bu}$ araştırmanın amacı sosyal bilgiler öğretmen adaylarının sosyal medyadaki değerlerini ve bu değerlerini nasıl yansıttıklarını belirlemektir. Araştırmada nitel araştırma yaklaşımı kapsamında fenomenoloji deseni kullanılmıştır. Araştırmanın katılımcılarını Türkiye'de bir devlet üniversitesinde Eğitim Fakültesinde Sosyal Bilgiler Öğretmenliği programına devam eden öğrenciler oluşturmaktadır. Araştırma verileri 12 öğretmen adayı ile gerçekleştirilen yarı yapılandırılmış görüşmeler yoluyla elde edilmiş ve verilerin analizinde tümevarımsal analiz yaklaşımı benimsenmiştir. Araştırma sonunda öğretmen adaylarına göre bireylerin sosyal medyada ihmal ettikleri değerler "saygı", "özel yaşamın gizliliği”, "tarafsızlık”, "sabırlı olma” ve "etik değerler" biçiminde sıralanmıştır. Bireylerin yansıttıklarını düşündükleri değerler arasında ise öncelikli olarak "dayanışma", "saygı", "yardımseverlik”, “duyarlılık" ve "sevgi” değerinin bulunduğu belirlenmiştir. Öğretmen adayları kendilerinin sosyal medyada ihmal ettiği değerleri "etik değerler", "sabırlı olma”, "tarafsızlık", "vatanseverlik”, "başkalarını düşünme" ve "duyarlılık" olarak belirtmiştir. Sosyal medyada yansıttıklarını düşündükleri değerlerin başında ise "saygı”, “duyarlılık”, “etik değerler”, “yardımseverlik” ve "dürüstlük”

\footnotetext{
${ }^{1}$ Bu makale 23-25 Nisan 2015 tarihinde 4. Uluslararası Sosyal Bilgiler Eğitimi Sempozyumu'nda sözlü bildiri olarak sunulan çalışmaya dayalı olarak hazırlanmıştır.

${ }^{2}$ Yard.Doç.Dr., Anadolu Üniversitesi, Eğitim Fakültesi, İlköğretim Bölümü, hidirk@anadolu.edu.tr

${ }^{3}$ Doç.Dr., Anadolu Üniversitesi, Eğitim Fakültesi, İlköğretim Bölümü, tcengelci.kose@gmail.com

${ }^{4}$ Arş.Gör., Anadolu Üniversitesi, Eğitim Fakültesi, İlköğretim Bölümü, ondereryilmaz@anadolu.edu.tr

Geliş tarihi: 14.11.2016, Kabul tarihi: 23.04.2017
} 
gelmektedir. Araştırmada elde edilen sonuçlar ışı̆̆ında sosyal medyada değerlerin yansıtılması konusunda öneriler getirilmiştir.

Anahtar Sözcükler: Sosyal bilgiler, değerler, sosyal medya 


\section{Giriş}

Bilim, hızlı teknolojik değişim ve iletişim alanındaki gelişmeler bilgi çağının temel özellikleri olarak göze çarpmaktadır. İnternet, bireylerin birbirleriyle herhangi bir sınırlama olmaksızın iletişim kurmalarını sağlamakta, istedikleri zaman istedikleri bilgiye ulaşmalarını olanaklı kılmakta ve düşüncelerini özgür biçimde ifade etmelerinin yolunu sunmaktadır. İletişim araçlarındaki internet temelli gelişmeler de günlük yaşamı gözle görülür biçimde değiştirmiştir. Kişisel bilgisayarların yaygınlaşması, internet ve sosyal ağların cep telefonu teknolojileri tarafından desteklenmesi ile iletişim çok farklı bir boyut kazanmıştır (Şendeniz, 2014).

Teknolojik gelişmeler ve değişmeler yaşamın her alanında olduğu gibi eğitimde de etkisini göstermektedir. İnternet ve diğer medya araçları yoluyla öğrencilere küresel çeşitlilik gibi konularla ilgili etkin öğrenme deneyimi sağlanmaktadır. Teknolojik olanaklar öğrencilerin bilginin yapılandırılmasına aktif katılımını, aralarında işbirliği yapmalarını ve bilgilerini gerçek yaşam durumlarına transfer etmelerini kolaylaştırır (Glimps ve Ford, 2008). Eğitim amaçlı kullanımların yanı sıra öğrencilerin günlük yaşamlarında da internet ve sosyal medya önemli yer tutmaktadır. Özellikle yükseköğretim düzeyinde öğrenciler günlük yaşam iletişimlerinin önemli bir bölümünü sanal ortamlarda gerçekleştirmektedir. Sosyal medya "iletişim, işbirliği ve yaratıcı ifade amacıyla kullanılan, İnternetin sosyal yönünü vurgulayan, Web 2.0 ve sosyal yazılım terimlerinin yerine kullanılan çeşitli iletişim ağı araçları ya da teknolojilerini ifade eden 21. yüzyıl terimi” (Dabbagh ve Kitsantas, 2011) olarak tanımlanmaktadır. Sosyal medya teknolojisi içerik oluşturma, fotoğraf paylaşma, beğeniyi gösterme ve oyun içinde etkileşimde bulunma gibi çeşitli işlemlerle günlük yaşamın önemli bir parçası durumuna gelmiştir. Özellikle teknolojinin öğrencilerin iletişimi, işbirliği ve öğrenmesi için önemli bir araç olarak kullanıldığı üniversitelerde çok daha yaygın biçimde kullanılmaktadır (Tess, 2013).

Sosyal bilgiler dersi öğrencilerin insanlar, yerler, kültürler, sistemler ve çeşitli doğal ve sosyal problemlerle ilgili konuları öğrendiği bir derstir. Öğrenciler bu derste yalnızca yaşamla ilgili bilgi ve olayları öğrenmekle kalmaz; onlar üzerinde derinlemesine ve eleştirel düşünme firsatı da bulur (Parker, 2010). Bu dersi yürütecek sosyal bilgiler öğretmen adaylarının da yakın çevrelerinde ve dünyada meydana gelen olaylara karşı duyarlı olmaları, bu konular üzerinde eleştirel düşünmeleri beklenmektedir. $\mathrm{Bu}$ da sosyal bilgiler öğretmen adaylarının sosyal 
medyayı bilinçli biçimde kullanmaları, sahip oldukları değerleri sosyal medyada da doğru biçimde yansıtmaları ile ilişkilidir.

"Davranışlara rehberlik eden ilkeler ve temel inançlar, eylemlerin iyi ya da istenilen olarak değerlendirilmesine olanak sağlayan standartlar" (Halstead ve Taylor, 2000, s.169) biçiminde tanımlanan değerler toplum yaşamında önemli bir yere sahiptir. Bireylerden beklenen ailede kazanmaya başladıkları, okulda geliştirmeye devam ettikleri değerleri günlük yaşamın her alanında göstermeleri; değerlerini davranışlarına yansıtmalarıdır. Değerler yüz yüze iletişsimde olduğu kadar sosyal medya kullanımında da önem taşımaktadır. Bununla birlikte sosyal medya kullanımı temel değerleri etkileyen sosyal normlar üzerinde büyük değişimde rol oynamaktadır. Kullanıcının iletiyi pasif biçimde aldığı televizyonun aksine Facebook, Youtube gibi siteler kullanıcının içeriği oluşturmasına, başkalarıyla paylaşmasına ve başkalarının oluşturduğu içerikle ilgili yorum yapmasına olanak sağlamaktadır. Sosyal medya sitelerinde bireyler kişisel bilgilerini paylaşmakta, yaşamlarına ilişkin fotoğrafları yayınlamaktadır. $\mathrm{Bu}$ da yaşamlarını toplumla paylaştıklarını göstermektedir (Maras, 2015; Swigger, 2012, Zhao ve Liu, 2015). Kişisel paylaşımlar yanında bireyler ve aktivistler sosyal medyayı küresel düzeyde birbiriyle iletişim kurmak, seslerini duyurmak, kendi politik görüşlerini açıklamak ve kamuoyu oluşturmak için de bir yol olarak görmektedirler. Bu bakımdan sosyal medyanın kişinin görüşlerini açıklaması ve paylaşmasının yanı sıra özel bilgilerinin korunması ve kişinin güvenliği üzerindeki etkisinin de anlaşılması önem taşımaktadır (Gupta ve Brooks, 2013). Sanal ortamdaki paylaşımların etki alanı düşünüldüğünde bireylerin sanal ortamda yansıttıkları değerlerin de aynı derecede önemli olduğu görülmektedir. Bireylerin sanal ortamda yansıttıkları değerlerin farkında olması ve sosyal medyayı bilinçli bir biçimde kullanması sosyal medyanın toplumsal yaşama katkısı bakımından önemlidir.

Öğretmen adaylarının sosyal medya kullanımları ile ilgili çalışmalara bakıldığında öğretmen adaylarının sosyal bilgiler eğitiminde sosyal medya kullanımına ilişkin görüşleri (Kahveci, 2015), Facebook’ta zorbalık yapma ve zorbalığa maruz kalma durumlarının incelenmesi (Baran, Keskin ve Genç), sosyal ağ sitelerini kullanma durumlarına göre sosyal beceri düzeylerinin incelenmesi (Hark Söylemez, 2015) sosyal ağlara bağımlılığının belirlenmesi (Çam ve İşbulan, 2012) gibi çeşitli çalışmalar göze çarpmaktadır. Bunların yanı sıra üniversite öğrencilerinin ve öğretmen adaylarının problemli internet kullanım davranışlarını inceleyen (Deatherage, Servaty-Seib ve Aksoz, 2014; Morahan-Martin ve Schumacher, 2000; Öztürk ve Kaymak Özmen, 2011) çalışmalar da alanyazında önemli yer tutmaktadır. Günümüzde giderek 
artan sayıda birey zamanını sanal ortamda ve sosyal ağlarda geçirmekte, bu ortamları etkili biçimde kullanmaktadır. Bu durum da vatandaşlık gibi kimi konuların bireyler tarafından sanal ortamda nasıl algılandığına ilişkin araştırmaların yapılmasını gündeme getirmiştir (Özmen ve Er, 2012). Genel vatandaşlık algısı yanında öğretmen adaylarının yaşamlarında davranışlarına yön veren değerleri sosyal medyada nasıl yansıttığının ve sosyal medyada diğer bireylerin yansıttıkları değerlere ilişkin görüşlerinin de araştırılması önem taşımaktadır. Bu araştırma sözü edilen gereksinimden kaynaklanmıştır.

Araştırmanın genel amacı sosyal bilgiler öğretmen adaylarının sosyal medyadaki değerlerini ve bu değerlerini nasıl yansıttıklarını belirlemektir. Bu genel amaç doğrultusunda araştırmada şu sorulara yanıt aranmıştır:

- Sosyal bilgiler öğretmen adaylarına göre diğer bireylerin ve kendilerinin sosyal medyada gösterdikleri ve ihmal ettikleri değerler nelerdir?

- Sosyal Bilgiler öğretmen adaylarına göre değerler, günlük yaşamda ve sosyal medyada nasıl farklılık göstermektedir?

- Sosyal bilgiler öğretmen adaylarının sosyal medyada yansıtılmasını gerekli gördüğü değerler nelerdir?

- Sosyal bilgiler öğretmen adaylarının sosyal medyada değerlerin gösterilmesi için önerileri nelerdir?

\section{Yöntem}

\section{Araştırmanın Modeli}

Sosyal Bilgiler öğretmen adaylarının sosyal medyada gösterdikleri değerlerin ne olduğunu anlamayı ve açıklamayı amaçlayan bu araştırmanın deseni, nitel araştırma desenlerinden fenomenolojidir. Fenomenoloji, deneyimlerimizin anlamı veya doğası hakkında derinlemesine bir anlayışın kazanılmasını amaçlar. Fenomenolojik araştırmalarda araştırmacılar, çalışma grubuna dahil olan katılımcıların araştırmaya konu olan fenomeni nasıl algıladıklarına ve nasıl deneyimlediklerine odaklanırlar (Patton, 2014). Bu çalışmada da öğretmen adaylarının değerlerini sosyal medyada nasıl ortaya koyduklarını belirlemek amacıyla fenomenolojik yaklaşımı benimsenmiştir. 


\section{Çalışma Grubu}

Araştırmanın çalışma grubunun belirlenmesinde amaçlı örnekleme yöntemlerinden ölçüt örneklemeden yararlanılmıştır. Ölçüt örnekleme yönteminde araştırmanın amacına göre bir dizi kriter belirlenir ve çalışma grubu bu kriterlere uygun kişiler tarafından oluşturulur (Yıldırım ve Şimşek, 2013, s. 140). Bu araştırmada çalışma grubu bir devlet üniversitesinde Sosyal Bilgiler Öğretmenliği Programı'nda öğrenim gören, programda seçmeli ders olarak açılan Dijital Vatandaşlık Eğitimi ile Sosyal Bilgilerde Değer Eğitimi derslerinin her ikisini de almış olan 12 öğretmen adayından oluşmaktadır. Öğretmen adaylarından dördü kadın, sekizi erkektir. Ayrıca çalışma grubundaki sekiz öğrenci üçüncü sınıf öğrencisiyken, dördü dördüncü sınıf öğrencisidir. Belirtilen iki derste öğretmen adaylarının hem sosyal medyaya hem de değerler ve değerler eğitimine ilişkin eğitim almış olmaları ve bu nedenle sosyal medya ve değerler konusunda belirli düzeyde bilgi sahibi olmaları ve gözlemlerini daha iyi yansıtabilecekleri düşünülmüştür.

\section{Veri Toplama Aracı}

Araştırmada veri toplama aracı olarak yarı yapılandırılmış görüşme kullanılmıştır. Yarı yapılandırılmış görüşmelerin, görüşülen kişinin kendini ifade etmesi ve gerektiğinde derinlemesine bilgi sağlama gibi avantajları bulunmaktadır (Büyüköztürk, Kılıç Çakmak, Akgün, Karadeniz ve Demirel, 2012, s. 152). Yarı yapılandırılmış görüşmeler için hazırlanan yarı yapılandırılmış görüşme formunun oluşturulmasında öncelikle alan yazından yararlanılarak sorular oluşturulmuş ve taslak görüşme formu hazırlanmıştır. Hazırlanan taslak form Sosyal Bilgiler Eğitimi Anabilim Dalında görev yapan üç öğretim üyesine sunularak uzman görüşü alınmıştır. Uzmanlardan gelen dönütler çerçevesinde form tekrar gözden geçirilmiş ve veri toplama aracının taslağı oluşturulmuştur. Söz konusu veri toplama aracının anlaşı1ır olup olmadığını anlamak ve soruları geliştirmek, üç öğretmen adayını kapsayan bir pilot uygulama yapılmıştır. Pilot uygulamadan sonra yarı yapılandırılmış görüşme soruları araştırmacılar tarafından değerlendirilmiş, gerekli düzenlemeler yapılarak görüşme sorularına son şekli verilmiştir. Gerçekleştirilen tüm çalışmalar sonucunda görüşme formunda 8 soru yer almıştır. Görüşme formunda, öğretmen adaylarının sosyal medyada bireylerin ve kendilerinin genellikle yansıttıkları ve yansıtmadıkları değerler, günlük yaşam ve sosyal medyada yansıtılan değerler arasındaki farklılıklar, sosyal medyada en fazla dikkat ettikleri değerler ve sosyal medyada değerlere ilişkin olumlu bir kültür yaratmak amacıyla neler yapılabileceğine ilişki 
önerilerini ifade etmeye yönelik sorular yer almıştır. Ayrıca araştırmaya katılan öğretmen adaylarına yarı yapılandırılmış görüşmelerden önce görüşmelerin nasıl gerçekleştirileceği, verilerin nasıl saklanacağı ve verilerin nasıl analiz edileceğine ilişkin bilgiler verilmiş ve sözlü onayları alınmıştır. Görüşmeler 25 ile 30 dakika arasında sürmüştür.

\section{Verilerin Analizi}

Araştırma kapsamında elde edilen verilerin analizinde tümevarımsal analiz yaklaşımı benimsenmiştir. Çalışma grubu ile gerçekleştirilen yarı yapılandırılmış görüşmeler elektronik ortamda yazılı bir metin haline getirilmiştir. Verilerin analizinde NVIVO 10 paket programında yararlanılmıştır. İki araştırmacı kodlamayı ayrı ayrı yapmış ve en az \%80 oranında görüş birliğine varılan ortak kodlar temel alınmıştır. Veriler öğretmen adaylarının görüşlerinden doğrudan alıntılarla desteklenerek sunulmuştur.

\section{Bulgular}

Bu bölümde araştırma bulguları araştırma amaçları doğrultusunda başlıklar altında sunulmuş, bulgular öğrenci görüşlerinden doğrudan alıntılar yapılarak desteklenmiştir.

\section{Sosyal Bilgiler Öğretmen Adaylarına Göre Sosyal Medyada Görülen Değerler}

SBÖA'larına göre kendilerinin ve diğer bireylerin sosyal medyada gösterdikleri ve ihmal ettikleri değerlere ilişkin görüşleri Tablo 1'de verilmiştir.

\section{Tablo 1}

SBÖA'larına Göre Bireylerin ve Kendilerinin Sosyal Medyada Gösterdikleri ve İhmal Ettikleri Değerler

\begin{tabular}{l|l|l|l}
\hline $\begin{array}{l}\text { Diğer bireylerin sosyal } \\
\text { medyada ihmal ettikleri } \\
\text { değerler }\end{array}$ & $\begin{array}{l}\text { Diğer bireylerin sosyal } \\
\text { medyada yansıttıkları } \\
\text { değerler }\end{array}$ & $\begin{array}{l}\text { SBÖA'larının sosyal } \\
\text { medyada ihmal ettikleri } \\
\text { değerler }\end{array}$ & $\begin{array}{l}\text { SBÖA'larının sosyal } \\
\text { medyada yansıttıkları } \\
\text { değerler }\end{array}$ \\
\hline $\begin{array}{l}\text { Saygı } \\
\text { Özel yaşamın gizliliği }\end{array}$ & $\begin{array}{l}\text { Dayanışma } \\
\text { Saygı }\end{array}$ & $\begin{array}{l}\text { Etik değerler } \\
\text { Sabırlı olma }\end{array}$ & Saygı \\
Tarafsılık & Yardımseverlik & Tarafsılılık & Etik değerler \\
Sabırlı olma & Duyarlılık & Vatanseverlik & Dürüstlük \\
Etik değerler & Sevgi & Başkalarını düşünme & Eşitlik \\
Akademik dürüstlük & Özgürlük & Duyarlılık & Hoşgörü \\
Barış & Sorumluluk & Hoşgörü & Merhamet
\end{tabular}




\begin{tabular}{|c|c|c|c|}
\hline $\begin{array}{l}\text { Diğer bireylerin sosyal } \\
\text { medyada ihmal ettikleri } \\
\text { değerler }\end{array}$ & $\begin{array}{l}\text { Diğer bireylerin sosyal } \\
\text { medyada yansıttıkları } \\
\text { değerler }\end{array}$ & $\begin{array}{l}\text { SBÖA'larının sosyal } \\
\text { medyada ihmal ettikleri } \\
\text { değerler }\end{array}$ & $\begin{array}{l}\text { SBÖA'larının sosyal } \\
\text { medyada yansıttıkları } \\
\text { değerler }\end{array}$ \\
\hline Başkalarını düşünme & Etik değerler & Sevgi & Özgürlük \\
\hline Dürüstlük & Adil olma & Sorumluluk & Sorumluluk \\
\hline Sevgi & Barış & Bilimsellik & Adil olma \\
\hline Adil olma & Doğruluk & Sayg1 & $\begin{array}{l}\text { Aile birliğine önem } \\
\text { verme }\end{array}$ \\
\hline Alçak gönüllülük & Sadakat & Yardımseverlik & Başkalarını düşünme \\
\hline Çalışkanlık & Hukukun üstünlüğü & Misafirperverlik & Hukukun üstünlüğü \\
\hline Doğruluk & $\begin{array}{l}\text { Sağlıklı olmaya önem } \\
\text { verme }\end{array}$ & & İnsan onuru \\
\hline Ahlaki değerler & & & Bağımsızlık \\
\hline Aile birliğine önem verme & & & Danışma \\
\hline Duyarlilık & & & Doğruluk \\
\hline Hukukun üstünlüğü & & & Özel yaşamın gizliliği \\
\hline İnsan onuru & & & Tarafsızlık \\
\hline Merhamet & & & Sabirlı olma \\
\hline Özgürlük & & & Vatanseverlik \\
\hline
\end{tabular}

Tablo 1'de görüldüğü gibi, SBÖA'larına göre bireylerin sosyal medyada ihmal ettikleri değerler arasında öncelikli olarak "saygı", "özel yaşamın gizliliği”, "tarafsızlık”, "sabırlı olma”, “etik değerler" bulunmakta iken bireylerin yansıttıklarını düşündükleri değerler arasında ise öncelikli olarak "dayanışma”, "saygı”, “yardımseverlik”, “duyarlılık” ve "sevgi” bulunmaktadır. Sosyal bilgiler öğretmen adayları tarafindan "saygı”, “etik değerler”, "barış”, “sevgi”, “adil olma”, “doğruluk”, “hukukun üstünlüğü” ve “özgürlük” bireylerin hem ihmal ettiği hem de yansıttıkları değerler olarak ifade edilmiştir. Örneğin saygı değerine ilişkin olarak Aytaç "Sosyal medyada genel değerlere bakacak olursak saygı var. Saygı insanların iletişim kurması için, sağlıklı bir şekilde birbirini anlaması için vardır” demiş ve saygının özellikle sosyal medyada sağlıklı bir iletişimdeki rolüne atıfta bulunmuştur. Bahadır ise "Karşı tarafin düşüncesine çok fazla saygı gösterilmiyor. Çünkü sosyal medyada yanında başka biri yok, konuştuğun zaman gördüğün başka kimse yok. Rahatlıkla o düşüncelerini yazabiliyorsun ve buna karşı bir tepki de direk sana karşı gelmiyor. Yazdıkların üzerine oluyor” biçimindeki görüşüyle ortamın sanal olmasının ve bireylerin karşılarında başkası yokmuş gibi davranmalarının birbirine saygı göstermemesine neden olduğunu ifade etmiştir.

Özel yaşamın gizliliği ise SBÖA'larına göre bireylerin sosyal medyada ihmal ettikleri değerler arasında en fazla sıralanan ikinci değer olmuştur. Bu konuda görüş belirten Onur “Özel yaşamın gizliliği hani herkes bir şeyler paylaşıyor. Hani bende paylaşıyorum bazen de, çok sık paylaşmam. Özel yaşamın gizliliğini koruma yok artık herkes gerekirse hemen bir yer bildirimi falan şuradayım, buradayım falan o pek hani bir güzel değil ’ biçimindeki görüşüyle özel yaşam 
gizliliğinin sosyal medyada ihmal edildiğini vurgulamış, çok sık olmasa da kendisinin de benzer davranışlarda bulunduğunu ifade etmiştir.

SBÖA'ları bireylerin sosyal medyada yansıttığını düşündüğü değerler incelendiğinde özellikle “dayanışma”, “yardımseverlik” ve "duyarlılık” gibi değerlerin ön plana çıktığı görülmektedir. Öğretmen adayları bu konuda görüşlerini belirtirken özellikle sosyal medyanın toplumda duyarlılık oluşturma, dayanışmayı kuvvetlendirme gibi özelliklerinin yansıtıldığını ifade etmiş ve güncel örneklerle bu durumu desteklemişlerdir. Örneğin Onur "İşte Özgecan olayı falan oldu. O tür konulardan böyle toplumu böyle derinden etkileyen olaylar olduğu zaman duyarlılık değerini ortaya koyuyor”, Aytaç ise “En yakın örnĕ̆i Özgecan örneği mesela. Gerçekten insanlar bir dayanışma ortamı yarattılar" ifadeleriyle toplumda meydana gelen olayların sosyal medyada duyarlılık oluşturma ve dayanışmayı sağlama açısından etkili olduğunu belirtmişlerdir.

Tablo 1'de görüldüğü gibi SBÖA'larının sosyal medyada ihmal ettiği değerlerde ise ön plana çıkanlar "etik değerler", "sabırlı olma”, "tarafsızlık", "vatanseverlik", "başkalarını düşünme” ve “duyarlılık”tır. SBÖA'larının sosyal medyada yansıttıklarını düşündükleri değerlerin başında ise "saygı”, “duyarlılık”, “etik değerler”, “yardımseverlik” ve “dürüstlük” gelmektedir. "Sayg1", “duyarlılık”, “etik değerler”, “yardımseverlik”, "hoşgörü”, "başkalarını düşünme”, "sabırlı olma", "vatanseverlik" gibi değerler SBÖA'larının kendilerinin hem ihmal ettiği hem yansıttığını düşündüğü değerler arasında yer almıştır. Bu bağlamda ön plana çıkan etik değerlere kimi öğretmen adayları göz ardı ettiklerini belirtirken kimi öğretmen adayları da bu değere uygun davrandıklarını belirtmişlerdir. Örneğin Ercan aşağıda yer alan görüşüyle, farkındalığı olmasına rağmen etik değerlere özellikle sosyal medyada bilgiyi uygun biçimde kullanma ve aşırma yapma anlamında dikkat etmediğini belirtirken, Rüya ise aşağıda yer alan görüşüyle özellikle diğer bireylerin gizlilik ve güvenliğine dikkat etme, onlara saygı duyma, hakaret etmeme bağlamında etik davranışlarda bulunduğunu ifade etmiştir.

"Aslında kendimizi eleştirecek olursak da bazen etik değerleri özellikle ihlal ettiğimiz olabiliyor. Şu şekilde oluyor; bu ortamlarda birçok bilgi var bilgiyi kullanırken kaynağını belirtmeden kendimiz yapmışız gibi insanlara yansitabiliyoruz. Bu kavram çok önemli, emeğe saygı olması gerekir. Ama biz bunu farkl şekillerde duyduğumuz kaynă̆ belirtmeden insanlara aktarabiliyoruz. Bu da o kişinin oluşturduğu bilgiye haksızlık ettiğimizi düşündürüyor bize. Bu şekilde ihlal ettiğim söylenebilir." (Ercan) 
"Etik değerlerde kişilere saygı duymaya, onları görüşlerinden dolayı dışlamamaya yada nasıl söyleyeyim kaba tabirle saçma oluyorsa bile bunu gayet uygun bir dille ifade etme, kaba saba sözlere başvurmamak, insanları kırmama bu şekilde ve gizlilik yani onların izin vermediği bir arkadaşın resmini paylaşmak diyebiliriz. İzin vermiyor ise paylaşmamak şeklinde." (Rüya)

SBÖA'larının kendilerinin sosyal medyada ihmal ettikleri değerler arasında en fazla sıralanan değerlerden biri "sabırlı olma"dır. SBÖA'ları özellikle sosyal medyada sabırlı davranmayıp, düşünmeden, heyecanla ve hızlıca yapılan yorumların sorunlara neden olduğunu belirtmişlerdir. Metin bu konudaki görüşünü şöyle ifade etmiştir:

"Şimdi böyle ben çabuk sinirlenen bir insanım. Atıyorum hani toplumda bir aksaklık var duyarsız bir insan bir aksakliğg hani görmezden geliyor. Onunla ilgili bir paylaşım yapıyor. Onu haklı göstermeye çalışlyor mesela ben bir ana orda patlayabilirim. Böyle bir örnek var. Güncel bir olay hakkında. Bir arkadaşım bir paylaşımda bulunmuştu. Kendi sınıf arkadaşım ve bende dayanamadım hemen onun gönderisine yorum yaptım. Biraz gözünü aç falan filan dedim işte. Ama tabi küfür içeren şeyler değildi ama belki onu biraz rencide edecek cümleler vardı içinde. Orda mesela biraz sabırsız davrandı̆̆ımı düşünüyorum. Belki o arkadaşım bana dile getirmedi ama içten içe biraz kırıldı bana” (Metin).

Tablo 2 incelendiğinde SBÖA'larının bireylerin sosyal medyada ihmal ettikleri değerlere daha fazla atıfta bulundukları, kendilerinin ihmal ettikleri değerlerin daha az olduğu ve benimsedikleri değerlerin ise fazla olduğu görülmektedir. Bu durum, SBÖA'larının kendileri haricindeki bireylerin sosyal medyada ihmal ettikleri değerlerin daha fazla olduğunu düşündüklerini göstermektedir. Ayrıca araştırmanın gerçekleştirildiği katılımcıların dijital vatandaşlık eğitimi ve değer eğitimi derslerini almış olmaları, sosyal medyada değerleri daha fazla benimsemelerinin nedenlerinden biri olabilir.

\section{Sosyal Bilgiler Öğretmen Adaylarına Göre Günlük Yaşamda ve Sosyal Medyada Görülen Farklı Değerler}

SBÖA'larına göre bireylerin ve sosyal bilgiler öğretmen adaylarının günlük yaşam ve sosyal medya arasında dikkat ettikleri değerlerdeki farklılaşmalar karşılaştırmalı olarak Tablo 2'de yer verilmiştir. 
Tablo 2

SBÖA'larına Göre Günlük Yaşamda ve Sosyal Medyada Görülen Farklı Değerler

\begin{tabular}{l|l}
\hline Bireylerin değerlerindeki farklılaşmalar & SBÖA'larının değerlerindeki farklılaşmalar \\
\hline Saygı & Duyarlılık \\
Dayanışma & Saygı \\
Duyarlılık & Bağımsızlık \\
Doğruluk & Çalışkanlık \\
Adil olma & Hoşgörü \\
Tarafsızlık & Bilimsellik \\
Vatanseverlik & Özgürlük \\
Akademik dürüstlük & Sorumluluk \\
Eşitlik & Yardımseverlik \\
Bağımsızlık & \\
Alçakgönüllülük & \\
Başkalarını düşünme & \\
Çalışkanlık & \\
Özgürlük & \\
Sabırlı olma & \\
Hoşgörü & \\
Sevgi & \\
Temizlik & \\
İnsan onuru & \\
Sorumluluk & \\
Yardımseverlik & \\
\hline
\end{tabular}

Tablo 2'de görüldüğü gibi, SBÖA'larına göre bireylerin gerçek yaşam ve sosyal medya arasında farklılaştığını düşündügü değerlerin başında "saygı", "dayanışma", "duyarlılık", “doğruluk" ve "adil olma” gelmektedir. Bu bağlamda kimi öğretmen adaylarının görüşlerine aşağıda yer verilmiştir:

"Saygı değerinin çok fazla farklılık gösterdiğini düşünüyorum açıkçası. Sosyal medyada biraz daha bağımsız olunduğu için aslında biraz daha tepkilerin uzağında olunduğu için saygısızlık yapılabiliyor aslında orda biraz daha sivrilebiliyorsun." (Nazan)

"Dayanışma anlamında diyebilirim. Hani facebookta mesela beğeniyor dayanışmanın olduğunu gösterip sosyal medyada gösteriyor ama gerçek hayatta olduğu zaman bunu pek dayanışmaya pek yansitmıyor. Hani katılmıyor mesela görüss sunduğu programa veya eyleme falan katılmıyor." (Onur)

"Günlük yaşamda birey kendisi baklyorsun çok sessiz hiç tarafsı bir tarafi yok, bir duyarlılı̆̆ yok ama sosyal medyaya gittiğin baktığında o kişi gayet duyarl, her türlü siyasi görüşe, dünya görüşüne, dünya olaylarına duyarlı işte onlar hakkında bilgi sahibi olan insanlar bunu gerçek yaşamına yansımayabiliyor. Sosyal medyada yansitabiliyor gerçek yaşamda baskın hissediyor kendini sosyal medyada daha mi çok özgür hissediyor tam olarak bilinmez ama herhalde daha özgür hissettiği için orda paylaşımlarını gerçekleştiriyor. Normal yaşamda çok sessiz bir insan sosyal medyada çok farklı olabiliyor" (Ozan) 
Öğretmen adaylarının görüşlerinde dikkat çeken en önemli nokta bireylerin sosyal medyada benimsedikleri kimi değerleri gerçek dünyaya yansıtmamalarıdır. Öğretmen adayları bu durumun nedenini ise özellikle ortamın sanal olmasına ve daha özgür olmasına bağladıkları görülmektedir. Öğretmen adayları diğer bireylerin bu ortamdaki davranışlarının her hangi bir sonucunun olmadığını düşündüklerini ve bu nedenle bireylerin sosyal medyada ve gerçek yaşamda benimsedikleri değerler arasında farklılaşmaların meydana geldiğini ifade etmektedirler.

SBÖA'larına göre kendilerinin gerçek yaşam ve sosyal medya arasında farklılaştığını düşündüğü değerlerin başında ise "duyarlılık", "saygı”, "bağımsızlık”, “çalışkanlık” ve "hoşgörü" gelmektedir. Öğretmen adaylarının görüşlerine bakıldığında özellikle gerçek yaşamda benimsedikleri kimi değerleri sosyal medyada yansıtmadıklarını ifade ettikleri görülmektedir. Nil bu konudaki görüşünü “Gerçek hayatta duyarlı olmaya çalışıyorum ama medyada belki es geçtiğim olabiliyor o konuda” biçiminde ifade ederken, Rüya ise "şimdi saygl dediğimiz zaman kendi aramızda örneğin günlük hayatta konuşuyoruz. Farklılıklara saygı olarak ele alıyorum. Sosyal Bilgiler öğrencisi olduğumuz için daha çok bu konular üzerinde duruyoruz. Etnik farklılıklar vs. farklılıklara saygı diye kendi aramızda konuşuyoruz. Ne bileyim sosyal medya olsun dijital ortamda olsun gördüğümüz şeylerde bazen üzülüyoruz ama bizi yaralayan bir bize dokunan, иси bize dokunan bir şey olduğu zamanda o sayglyı yitiriyoruz” biçimindeki görüşüyle sosyal bilgiler öğretmen adayı olarak farklılıklara saygı değerine genelde dikkat ettiğini ancak sosyal medyada zaman zaman kendisini yakından ilgilendiren konularda bu saygıyı yitirdiğini ifade etmektedir.

Tablo 2'de görüldüğü gibi SBÖA'larının gerçek yaşam ve sosyal medyada arasında dikkat ettikleri değerlerdeki farklılaşmadan daha az söz ettikleri görülmektedir. Bu durum gerçek yaşam ve sosyal medya arasındaki değerlerinin farklılaşmamasına dikkat ettiklerini göstermektedir. Özellikle bu konuda öğretmen adaylarının dijital vatandaşlık eğitimi dersi almalarının ve bu ders kapsamında gerçek ve sanal yaşam arasındaki bağı anlatmaya çalışan etkinlik ve uygulamaların rolü olduğu söylenebilir. Sosyal medyada değerlere ilişkin olumlu bir kültür oluşturma amacıyla yapılması gerekenler sorulduğunda öğretmen adaylarının öncelikle eğitimle ve dijital vatandaşlıkla ilgili eğitimlerin gerekliliğini belirtmeleri bu durumu desteklemektedir. 


\section{Sosyal Bilgiler Öğretmen Adaylarının Sosyal Medyada Yansıtılmasını Gerekli Gördüğü Değerler}

SBÖA'larının sosyal medyada yansıtılmasını gerekli gördügü değerlere göre Tablo 3'te yer verilmiştir.

Tablo 3

SBÖA'larına Göre Sosyal Medyada Yansıtılmasını Gerekli Gördüğ̈̈ Değerler

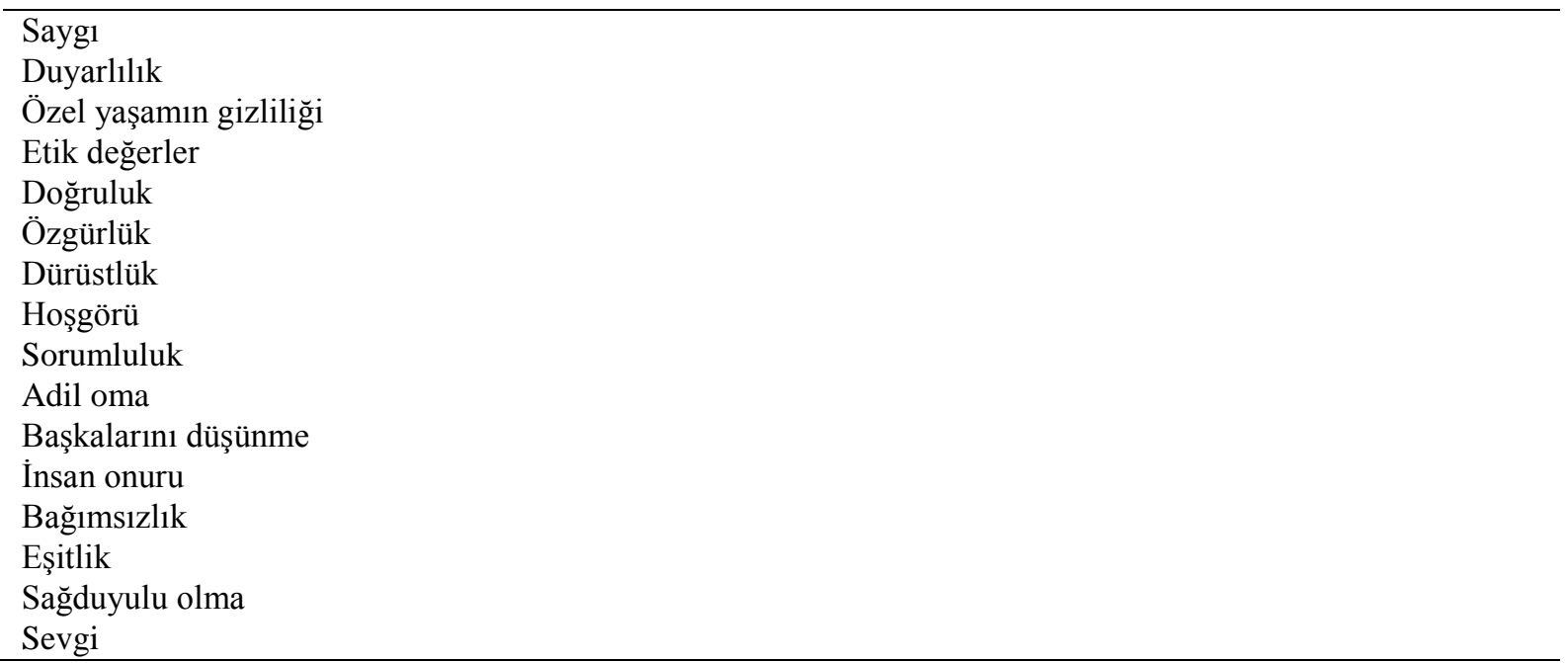

Tablo 3'te görüldügü gibi SBÖA'larının sosyal medyada yansıtılmasını gerekli gördükleri değerler arasında ön plana çıkanlar "saygı", “duyarlılık”, “etik değerler”, “özel yaşamın gizliliğgi” ve “doğruluk” olmuştur. Bu konuda kimi öğretmen adaylarının görüşleri şöyledir:

"İnsanların birbirleri ile kurduğu iletişimde en önemli şeylerden bir tanesi de saygldır. Saygl insanlarla iki insan kişi veya kuruluş arasındaki iletişimde önemlidir. Çünkü birbirlerine duyulan saygı ile iletişim gerçekleşebileceğini düşünüyorum. Bu şekilde saygı olmazsa zaten bir iletişimin varlığından söz edemeyiz." (Ercan)

"Ya ilk olarak ben duyarlılık derim. Şimdi şöyle sosyal medyada dediğim gibi karşıda birisini göremediğimizden dolayı daha rahat davranıyoruz. Ama aynı şeyleri gerçek ortamda karşımızda biri varken konuşmak çok daha zor oluyor. Çünkü o karşımızda onu görürüz. Vereceği tepkiyi bilmiyoruz. Bu konuda duyarlı olmall çünkü onunda inandlğg görüşler, düşünceler olabilir. Onu zedelemeden ona, düsüncelerine, ruh haline zarar vermeden biraz daha duyarlı biraz daha ılıml yaklaşılmasını tercih ederim." (Bahadır) 
“Adı üstünde özel biz artık sanal ortamda buna facebook dahil twitter dahil bütün sosyal mecralar internet siteleri her şeyimizi paylaşır olduk. Artık mesela ne bileyim örnek verecek olursak herkes nerde ne yaptığını biliyor artı. Chek-in yapıyoruz işte şuradayım, şununla fotoğraf çekiyorum. Kimlerle ilişkiniz olduğu bile ortada aşikâr bir durum. Bu bence pek etik bir durum değil. Ailesiyle beraber mesela atıyorum adam artık yemek yerken bile mutfakta otururken fotoğrafinı çekiyor paylaşıyor. Hani belli bir özeli kalmıyor, eşiyle özeli kalmıyor. Hani bunlar hiç yapılmasın demiyorum ama biz çoğu kez abartıyoruz o yüzden özel yaşamın gizliliği bence kesinlikle olmasl gerek.” (Metin)

Ercan'ın görüşünde belirttiği üzere, öğretmen adayları sosyal medyada yansıtılması gereken değerleri açıklarken özellikle iletişim kurma sürecini vurguladıkları ve bu ortamda saygının ön plana çıkarılması gerektiğini ifade ettikleri görülmektedir. Bunun yanı sıra özellikle karşıdaki bireylere duyarlı olmanın, özel yaşamın gizliliğine saygı duymanın ve paylaşımlarda bulunurken doğruluk değerinin göz önünde bulundurulması gerektiğini belirttikleri görülmektedir.

\section{SBÖA’larına Göre Sosyal Medyada Değerlerin Gösterilmesine İlişkin Önerileri}

SBÖA'larına göre sosyal medyada değerlere ilişkin olumlu bir kültür oluşturmak amacıyla yapılması gerekenlere Tablo 4’te yer verilmiştir.

Tablo 4

SBÖA'larına Göre Sosyal Medyada Değerlere İlişkin Olumlu Bir Kültür Oluşturmak Amacıyla Yapılmasi Gerekenler

\begin{tabular}{l|l}
\hline Eğitimle ilgili çalışmalar & Ailelere, öğretmenlere, öğrencilere yönelik bilinçlendirici eğitimler \\
& verilmesi \\
& Dersler açılması \\
& Seminerler düzenlenmesi \\
& Gerçek hayat değerlerin sanal ortama aktarma konusunda bilinçlendirme \\
& Sosyal medyanın doğru kullanımını destekleme \\
\hline Duyuşsal kazanımlarla ilgili & Değerler eğitimini destekleme \\
çalışmalar & Empati becerisini geliştirme \\
& Hoşgörülü olma \\
\hline Sanal ortam ve gerçek yaşam & Sanal ortam gerçek yaşam bağlantısını kuvvetlendirme \\
ilişkisini kurma konusundaki & Kamu spotları oluşturma \\
çalışmalar & Hukuki yaptırımları kuvvetlendirme \\
& Özel yaşam gizliliği farkındalığını arttırma \\
\hline
\end{tabular}

Tablo 4'te görüldüğü gibi SBÖA'ları sosyal medyada değerlere ilişkin olumlu bir kültür yaratmak amacıyla eğitimle ilgili, duyuşsal kazanımlarla ilgili, sanal ortam ve gerçek yaşam ilişkisini kurma ile ilgili çalışmalar yapılması gerektiğini ifade etmektedirler. SBÖA'ları 
tarafindan özellikle bu kapsamda eğitsel çalışmalara daha fazla vurgu yapıldığı görülmektedir. Örneğin Nazan' “Bunun önceliğinde tabi eğitim ve ögrretmenlere, bizlere çok iş düşüyor. Bunların eğitiminde sosyal medyanın ĕgitimi verilmesi gerekiyor başta öğrenciler olmak üzere”; Mert’te “.... O yüzden ilkokula bir sanal ortamda bir dijital vatandaşlık dersi gibi bir ders konulması gerektiğini bende düşünüyorum. Çünkü yani insanların normal vatandaş olmayı öğreniyorlar artık inkar edemeyeceğimiz bir sanal vatandaşlık ta var. Sanal bir hayat da artık aklyor. Belki ilerde daha fazla olacak. Belki bizim çocuklarımız daha haşır neşir olacak normal hayattan daha da öne geçecek belki normal sosyal hayatta şimdi bile öyle insanlar var. Biz yani böyle hiçbir değerin olmadığ hiçbir toplumsal mekanizmanın olmadı̆̆ bir anarşi var yani bizim sanal ortamda, sosyal medyada hiçbir şey yok herkes herkese diyebilir zannediyor her istediğini. Böyle düşünüyorum eğitim verilmeli yani”. Öğretmen adaylarının görüşlerinde sosyal medya kullanımına ilişkin olumlu bir kültür yaratmada eğitsel çalışmaların ilkokullardan itibaren gerçekleştirilmesi ve özellikle öğretmenin rolü vurgulanmaktadır.

SBÖA'ları eğitimin duyuşsal kazanımlarıyla ilgili değerler eğitiminin de sosyal medyada değerlere ilişkin olumlu bir kültür yaratmak amacıyla katkı sağlayacağı düşünülmektedir. Örneğin Nil "Özellikle değer eğitiminin artması ve sosyal medyayı nasıl kullanmak gerektiği, dijital ortamda nasıl faaliyetlerde bulunmak gerektiği bunları tam olarak çözebilirsek bunlarında çözüleceğini düşünüyorum." Bahadır ise "Ya değerler eğitimi hani çok fazla verilen bir şey değil hani çok fazla değerler eğitimi verilmiyor. Gerek ilkokul olsun gerek üniversitelerde olsun çoğu üniversitede olduğunu düşünmüyorum. Yok diye biliyorum yani. Değerleri en başta uygun bir şekilde bütün kitlelere anlatmamı gerekir” görüşleriyle bu durumu savunmaktadır. Bu bağlamda değerler eğitimi kapsamında sosyal medyaya ve dijital yaşama ilişkin değerlerin vurgulanmasının gerekliliği öğretmen adayları tarafından ortaya konulmaktadır.

SBÖA'ları sosyal medyada değerlere ilişkin olumlu bir kültür yaratmak amacıyla atılması gereken adımlardan birin ise sanal ortam ve gerçek yaşam ilişkisini kurma ile ilgili çalışmalara bağlamaktadır. Örneğin Metin “Öncelikle sanal ortamında gerçek yaşantı ile bağlı olduğunun ögretilmesi gerekiyor. Dediğim gibi sanal ortamda söylediklerimiz yarın öbür gün bizim karşımıza çıkabilir. Son dönemde yaşadığımız olaylarda bunu gayet net bir şekilde gösteriyor. Onları ayrı, sanal ortamı ayrı bir dünya olarak görmemek gerekiyor bence. Orada yazdıklarımıza, çizdiklerimize, söylemlerimize, karşımızdakinin de bir insan olduğunu unutmadan davranışlarımızı göstermemiz gerektiğini düşünüyorum. Bunun için tabi 
ögretmenlere büyük iş düşüyor. En başta ailelere anne babalara büyük iş düşüyor. Değerlerin tam olarak ne olduğunun gösterilmesi, değerlerin içini boşaltmadan gerçekte ne yapılmasının gerektiğinin söylenirse bence sanal ortam ve gerçek yaşam arasinda ki o bağ kurulur ve olumlu bir düşünce ortaya çıkar." Bu kapsamda öğretmen adayları tarafından sanal ortam ve gerçek dünya arasındaki bağı kurmada aile ve öğretmenlerin rolüne atıfta bulunulmuştur.

\section{Sonuç, Tartı̧̧ma ve Öneriler}

SBÖA'larına göre bireylerin sosyal medyada ihmal ettikleri değerler arasında öncelikli olarak "saygı", "özel yaşamın gizliliği”, "tarafsızlık", "sabırlı olma", "etik değerler” bulunmaktadır. Kakırman Yıldız (2012) da araştırmasında insanların mahremiyet ve gizliliği göz ardı ettiğini, utanma duygusunu yok ettiğini ve kıskançlık duygusunu derinleştirdiğini belirtmiştir. Sincar ve Uğurlu (2012) tarafından gerçekleştirilen araştırmada ise öğretmenlerin eğitimle ilgili katıldıkları çeşitli forum sayfalarında saldırganlık, takıntı ve saygısızlık gibi pek çok etik olmayan davranışla karşılaştıkları belirtilmiştir. $\mathrm{Bu}$ araşıırmada da özellikle öğretmen adaylarının kendi arkadaşları ve diğer kullanıııların sosyal medyada etik olmayan davranışlara başvurmalarını ön plana çıkardıkları görülmektedir.

SBÖA'larının bireylerin sosyal medyada yansıttığını düşündüğü değerler incelendiğinde ise özellikle "dayanışma", "yardımseverlik" ve "duyarlılık” gibi değerlerin ön plana çıktığı görülmektedir. Öğretmen adayları sosyal medyanın toplumda duyarlılık oluşturma, dayanışmayı kuvvetlendirme gibi özelliklerini ifade etmiş ve güncel örneklerle bu durumu desteklemişlerdir. Vural ve Bat (2010) sosyal medya olarak tanımlanan, kişiler arasında fotoğraf, video, metin ve videoya ilişkin karışık uygulamalar içeren uygulamaların sanal iletişime yeni bir boyut getirdiğini belirtmekte; sosyal medyanın katılımcılarını iletişim kurmaya cesaretlendirdiğini ve bu konuda geribildirimi önemsediğini öne sürmektedir. Bu bakımdan toplumsal olgu ve olayların sosyal medyada hızlı bir biçimde duyulduğu ve kişilerin bu olaylar üzerinde iletişim kurmasını kolaylaştırarak bir kamuoyu oluşturulmasına yardımcı olduğu söylenebilir. Solmaz, Tekin, Herzem ve Demir (2013) iletişim fakültesi öğrencileriyle gerçekleştirdiği araştırmada sosyal paylaşım ağlarının fotoğraf ve bilgi paylaşımı, bilgi sahibi olmak, mesaj göndermek ve almak, olayları ya da gündemi takip etmek ve görüş alışverişinde bulunmak gibi nedenlerle kullanıldığ 1 sonucuna ulaşılmıştır. Valenzuela, Arriagada ve Scherman (2012) Şili örneğinde sosyal paylaşım sitelerinin politik değişim ve demokrasinin 
gelişimindeki rolünü inceledikleri çalışmalarında 18-29 yaş arasındaki bireylerde Facebook kullanımının protestoya katılımda önemli bir unsur olduğu belirlenmiştir. Bu araştırmada da öğretmen adayları sosyal medyanın belirli toplumsal olaylarda dayanışmayı, yardımseverliği ve duyarlılığg artırdığını düşünmeleri sosyal medyanın kişileri belirli görüş etrafında birleştirdiği görüşüne katıldıkları biçiminde yorumlanabilir. Sosyal bilgiler öğretmen adayları tarafından "saygı", “etik değerler”, "barış", "sevgi”, "adil olma”, “doğruluk”, "hukukun üstünlüğü” ve "özgürlük” bireylerin hem ihmal ettiği hem de yansıttıkları değerler olarak ifade edilmiştir. Bu durum sosyal medyada farklı bağlamlarda farklı değerlerin ön plana çıkması ya da ihmal edilmesi biçiminde değerlendirilebilir.

SBÖA'larının kendilerinin sosyal medyada ihmal ettiği değerlerde ön plana çıkanlar "etik değerler", "sabırlı olma”, "tarafsızlık”, "vatanseverlik”, "başkalarını düşünme” ve “duyarlılık”tır. Rowe (2014), birçok üniversitede yöneticilerin öğrencilerin sosyal medyada öğretim elemanlarına ya da diğer öğrencilere karşı saldırgan ya da hakaret edici yorumlar içeren mesajlarından kaygı duyduklarını belirtmektedir. Üniversiteler ifade özgürlüğü ile görüşlerin sorumlu ve saygılı biçimde açıklanması arasındaki dengeyi bulmakta güçlük çekmektedir. $\mathrm{Bu}$ durum sosyal medyada etik değerler, başkalarını düşünme ve duyarlılığın ön plana çıkmasının önemli olduğu göstermektedir. SBÖA'larının sosyal medyada yansıttıklarını düşündükleri değerlerin başında ise "saygı", "duyarlılık", "etik değerler”, "yardımseverlik" ve "dürüstlük" gelmektedir. SBÖA etik değerler ve duyarlılık değerlerini hem ihmal ettiklerini hem de yansıttıklarını belirtmişlerdir. Sosyal medya denildiğinde öğretmen adaylarının hem gösterilen hem ihmal edilen değerler arasında bu değerleri belirtmeleri, etik değerler ve duyarlılığı sosyal medya için temel değerler olarak gördükleri biçiminde yorumlanabilir.

SBÖA'larının bireylerin sosyal medyada ihmal ettikleri değerlere sayıca daha fazla atıfta bulundukları, kendilerinin ihmal ettikleri değerlerin sayıca az olduğu ve benimsedikleri değerlerin ise fazla olduğu görülmektedir. Öğretmen adaylarının dijital vatandaşlık ve değer eğitimi derslerini almaları ihmal ettikleri değerlere daha az referansta bulunmalarının nedenlerinden biri olarak gösterilebilir. Özellikle dijital vatandaşlık eğitimi derslerinde etik olan ve olmayan değerlere, internet üzerinde iletişim kurarken nelere dikkat edilmesi gerektiğine, gizliliğin ve güvenliğin nasıl korunabileceğine, dijital ortamdaki haklara ve sorumluluklara, yasalara yer verilmesi, sanal ortam ve gerçek yaşam arasındaki bağ kuvvetlendirici etkinlikler gerçekleştirilmesi öğretmen adaylarının ihmal ettikleri değerlere daha az atıfta bulunmalarını sağladığı düşünülmektedir. SBÖA'larına göre kendilerinin gerçek 
yaşam ve sosyal medya arasında farklılaştığını düşündüğü değerlerin başında ise "duyarlılık", “saygı", "bağımsızlık”, “çalışkanlık” ve "hoşgörü” gelmektedir.

SBÖA'larının sosyal medyada yansıtılmasını gerekli gördükleri değerler arasında ön plana çıkanlar "saygı”, “duyarlılık”, “etik değerler”, “özel yaşamın gizliliğì” ve “doğruluk” olmuştur. Sayg1, etik, özel yaşamın gizliliği ve doğruluk değerleri özellikle dijital vatandaşlık, siber vatandaşlık, e-vatandaşlık, internet etiği gibi çalışmalarda üzerinde durulan ve dikkat edilmesi gereken önemli konulardır (Churches, Crockett ve Jukes, 2010; Farmer, 2010; Greenhow, 2010; Hollandsworth, Dowdy ve Donovan, 2011; Knorr, 2010; ISTE [International Society for Technology in Education], 2007; Ribble ve Bailey, 2007; Ribble, 2006; Willoughby ve Wood, 2008). Bu bağlamda öğretmen adaylarının ilgili değerlere atıfta bulunması alanyazın bağlamında vurgulanan ortak değerler konusunda farkındalıkları olduğunu göstermektedir. Debatin, Lovejoy, Horn ve Hughes (2009) lisans öğrencileri ile gerçekleştirdikleri çalışmalarında Facebook kullanıcılarının özel yaşamın gizliliği konusundaki farkındalıklarını, Facebook kullanımının yararları ve riskleri konusundaki algılarını araştırmışlardır. Araştırma sonunda kullanıcıların özel yaşamın gizliliği ile ilgili konuları bildiklerini iddia etmekle birlikte büyük oranda kişisel bilgilerini sisteme yükledikleri ve özel yaşamın gizliliği ile ilgili umursamaz bir tutum içinde oldukları belirlenmiştir. Öztürk ve Akgün (2012) tarafından gerçekleştirilen çalışmada da lisans öğrencileri özel bilgilerin korunması açısından sosyal medyayı güvenilmez olarak görmektedirler. Bu bağlamda özel yaşamın gizliliğinin öğretmen adayları tarafından sıklıkla vurgulandığı söylenebilir.

SBÖA'ları sosyal medyada değerlere ilişkin olumlu bir kültür yaratmak amacıyla eğitimle ilgili, duyuşsal kazanımlarla ilgili, sanal ortam ve gerçek yaşam ilişkisini kurma ile ilgili çalışmalar yapılması gerektiğini ifade etmektedirler. Chen, Hsieh, Mahmud ve Nichols (2014) bir haber sosyal paylaşım sitesinde insanların yorum yaparken kullandıkları sözcükleri analiz ederek kişisel değerlerini belirlemeye yönelik bir çalışma gerçekleştirmişlerdir. Araştırmada bireylerin sosyal medyada kullandıkları sözcüklerin onların değerlerini yordamada önemli bir unsur olduğu belirtilmiştir. Bu bakımdan bireylerin değer kazanımları ve bunları sosyal medyaya yansıtmaları büyük önem taşımaktadır. Ozan ve Odabaşı (2016) Öğretmenlik Uygulaması dersinde öğretmen adaylarına danışmanlık yapmak amacıyla sosyal medyanın etkisini inceledikleri çalışmalarında öğretmen adaylarının sosyal medyada kendilerini çok daha rahat ifade ettikleri sonucuna ulaşmışlardır. Bu bakımdan sosyal medyanın etkili ve doğru 
biçimde kullanımının öğretmen eğitimi açısından katkı sağlayıcı olduğu söylenebilir. Araştırmada elde edilen sonuçlar bağlamında şu öneriler getirilebilir:

- Öğretmen adaylarına sosyal medya kullanımı ile ilgili eğitimler verilebilir, ayrıca dijital vatandaşl1k eğitimine yönelik seçmeli dersler açılabilir.

- Öğretmen eğitimi programlarında sosyal medyanın etkisi ile ilgili farklı araştırmalar yapılabilir.

- Öğretmen eğitimi programlarında değerler eğitimi ile ilgili derslerde sanal ortamda değerler ve etik ile ilgili konulara yer verilebilir.

- Sosyal medyada değerlerin yeri konusunda farklı araştırmalar yapılabilir. 


\section{Kaynakça}

Baran, B., Keskin, E. ve Genç, Ş. (2014). Öğretmen adaylarının Facebook'ta zorbalık yapma ve zorbalığa maruz kalma durumlarının bazı değişkenlere göre incelenmesi. Journal of Instructional Technologies \& Teacher Education, 3(1), 34-43.

Büyüköztürk, Ş., Kılıç Çakmak, E., Akgün, Ö. E., Karadeniz, Ş. ve Demirel, F. (2012). Bilimsel araştırma yöntemleri (Geliştirilmiş 12. Baskı). Ankara: Pegem Akademi.

Chen, J., Hsieh, G., Mahmud, J. U. ve Nichols, J. (2014). Understanding individuals' personal values from social media word use. 17th ACM Conference On Computer Supported Cooperative Work \& Social Computing Bildiri Kitabı içinde (ss. 405-414). New York, NY: ACM.

Churches, A., Crockett, L., ve Jukes, I. (2010). The digital diet: Today's digital tools in small bytes: 21 st Century Fluency Series. Kelowna, BC: Corwin.

Çam, E. ve İşbulan, O. (2012). A new addiction for teacher candidates: social networks. Turkish Online Journal of Educational Technology, 11(3), 14-19.

Dabbagh, N. ve Kitsantas, A. (2011). Personal learning environments, social media, and selfregulated learning: A natural formula for connecting formal and informal learning. Internet and Higher Education, 15(1), 3-8. doi: 10.1016/j.iheduc.2011.06.002

Deatherage, S., Servaty-Seib, H. L. ve Aksoz, I. (2014). Stress, coping, and internet use of college students. Journal of American College Health, 62(1), 40-46.

Debatin, B., Lovejoy, J. P., Horn, A. ve Hughes, B. N. (2009). Facebook and online privacy: Attitudes, behaviors, and unintended consequences. Journal of Computer-Mediated Communication, 15(1), 83-108.

Farmer, L. (2010). 21. Century standarts for information literacy. Leadership, 39(4), 20-22.

Glimps, B. J. ve Ford, T. (2008). Using Internet technology tools to teach about global diversity. Clearing House: A Journal of Educational Strategies, Issues and Ideas, 82(2), 91-95.

Greenhow, C. (2010). A new concept of citizenship for the digital age. Learning \&Leading with Technology, 37(6), 24-25.

Gupta, R. ve Brooks, H. (2013). Using social media for global security. Somerset, NJ, USA: John Wiley \& Sons.

Halstead, J. M. ve Taylor, M. J. (2000). Learning and teaching about values: a review of recent research. Cambridge Journal of Education, 30(2), 169-203.

Harding, J. (2013). Qualitative data analysis: From start to finish. Sage Publication: California.

Hark Söylemez, N. (2015). Öğretmen adaylarının sosyal ă̆ sitelerini kullanma durumlarına göre sosyal beceri düzeylerinin incelenmesi (Yayınlanmamış yüksek lisans tezi). Dicle Üniversitesi, Diyarbakır.

Hollandsworth, R., Dowdy, L. ve Donovan, J. (2011). Digital citizenship in K-12: It takes a village. TechTrends, 55(4), 37-47. 
ISTE. (2007). National education technology standarts for students. http://www.iste.org/standards/nets-for-students/nets-student-standards-2007.aspx adresinden 1 Ağustos 2012 tarihinde alınmıştır.

Kahveci, N. G. (2015). Pre-service teachers' conceptions on use of social media in social studies education. International Journal of Progressive Education, 11(1), 82-100.

Kakırman Yıldız, A. (2012). Sosyal paylaşım sitelerinin dijital yerlilerin bilgi edinme ve mahremiyet anlayışına etkisi. Bilgi Dünyası, 13(2), 529-542.

Knorr, C. (2010). Be a good digital citizen: Tips for teens and parents. http://www.wuhsms.org/index.php/our-blog/technology/185-be-a-good-digital-citizentips-for-teens-and-parents adresinden 1 Ağustos 2012 tarihinde alınmıştır.

Maras, M. H. (2015). Unprotected speech communiicated via social media: what amounts to a true threat. Journal of internet law, 19(3), 3-9.

Morahan-Martin, J. M., ve Schumacher, P. (2000). Incidents and correlates of pathological internet use among college students. Computers in Human Behavior, 16(1), 13-29.

Ozan, Ş. ve Odabaşı, F. (2016). Sosyal medyada öğretmenlik uygulaması danışmanlık sürecine ilişkin öğrenci görüşleri. Ahi Evran Üniversitesi Kırşehir Eğitim Fakültesi Dergisi (KEFAD), 17(1), 599-613.

Özmen, C. ve Er, H. (2012). Sanal ortamda vatandaşl1k. Bartın Üniversitesi Eğitim Fakültesi Dergisi, 1(1), 204-2016.

Öztürk, E. ve Kaymak Özmen, S. (2011). Öğretmen adaylarının problemli internet kullanım davranışlarının, kişilik tipi, utangaçlık ve demografik değişkenlere göre incelenmesi. Kuram ve Uygulamada Ĕ̈itim Bilimleri, 11(4), 1785-1808.

Öztürk, M. ve Akgün, Ö. E. (2012). Üniversite öğrencilerinin sosyal paylaşım sitelerini kullanma amaçları ve bu sitelerin eğitimlerinde kullanılması ile ilgili görüşleri. Sakarya University Journal of Education, 2(3), 49-67.

Parker, C. W. (2010). Social studies education. W. Parker (Ed.). Social studies today: research and Practice (ss. 1-12). New York, NY: Taylor \& Francis. https://education.uw.edu/sites/default/files/u284/Parker.Chapter1.pdf adresinden 16 Ekim 2015 tarihinde alınmıştır.

Patton, M. Q. (2014). Nitel araştırma ve değerlendirme yöntemleri. (M. Bütün ve S. B. Demir çev. ed.). Ankara: Pegem Akademi.

Ribble, M. S. (2006). Implementing digital citizenship in schools: The research, development and validation of a technology leader's guide (Unpublished doctoral dissertation). Kansas State University, Kansas, USA.

Ribble, M. and Bailey, G. (2007). Digital citizenships in schools. Washington: ISTE.

Rowe, J. (2014). Student use of social media: when should the university intervene? Journal of Higher Education Policy and Management, 36(3), 241-256. 
Sincar, M., ve Uğurlu, C. T. (2012). Öğretmenlerin Forum Sayfalarında Karş1laştıkları Etik Problemler. Gaziantep University Journal of Social Sciences, 11(3), 737-758.

Solmaz, B., Tekin, G., Herzem, Z. ve Demir, M. (2013). İnternet ve sosyal medya kullanımı üzerine bir uygulama. Selçuk Üniversitesi İletişim Fakültesi Akademik Dergisi, 7(4), 2332.

Swigger, N. (2013). The online citizen: Is social media changing citizens' beliefs about democratic values?. Political Behavior, 35(3), 589-603.

Şendeniz, Ö. (2014). Toplumsal hareketler repertuvarı ve sosyal ağlar: HES muhalefeti örneği. E. Baştürk Akca (Ed.). Yeni Medya Pratikler Olanaklar içinde (s.155-174). Kocaeli: Umuttepe Yayınları.

Tess, P. A. (2013). The role of social media in higher education classes (real and virtual) - A literature review. Computers in Human Behavior, 29(5), A60-A68.

Valenzuela, S., Arriagada, A., ve Scherman, A. (2012). The social media basis of youth protest behavior: The case of Chile. Journal of Communication, 62(2), 299-314.

Vural, Z. B. A. ve Bat, M. (2010). Yeni bir iletişim ortamı olarak sosyal medya: ege üniversitesi iletişim fakültesine yönelik bir araştırma. Journal of Yasar University, 20(5), 3348-3382.

Willoughby, T., ve Wood, E. (Eds.). (2008). Children's learning in a digital world. Malden, MA: Blacwell Publishing.

Yıldırım, A. ve Şimşek, H. (2013). Sosyal bilimlerde nitel araştırma yöntemleri. (Genişletilmiş 9. basım.). Ankara: Seçkin Yayıncılık.

Zhao, H. ve Liu, J. (2015). Social media and collective remembrance. China perspective, 1, 4148. 